\title{
A Recent Approach for Development and Standardization of Ayurvedic Polyherbal Formulation (Churna) for Antioxidant Activity
}

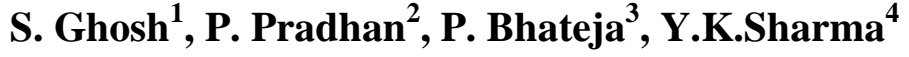 \\ Himachal Institute of Pharmaceutical Education \& Research, Nadaun (H.P) India
}

\begin{abstract}
In the Ayurvedic Pharmacopeia, many types of preparations are mentioned, one of them churna is a formulation, in this study, we are prepared a churna by following as per Ayurvedic pharmacopeia, by mixing with two Antioxidant herbal ingredients, it is a very essential preparation, known to be effective in all types of oxidation related disorders in cellular and molecular level in the living organs, the prepared formulation has been standardized by following modern scientific quality control procedures both for the raw material and finished product. The obtained values of physical and chemical parameters can be adopted to lay down new pharmacopoeial standards to be followed for traditional preparations of Antioxidant churna with batch-to-batch consistency. The Physicochemical constituents found to be present in the raw material used the preparation of Antioxidant churna possible facilitate the desirable therapeutic efficacy of the medicinal formulation, and also could help in knowing the underlying mechanisms of Pharmacological Action.
\end{abstract}

Keywords:- Standardization Process, Pharmacopoeial Standards, Antioxidant Churna, Ayurvedic Polyherbal Formulation.

\section{INTRODUCTION}

An antioxidant is a molecule capable of slowing or preventing the oxidation of other molecules. Oxidation is a chemical reaction that transfers electrons from a substance to an oxidizing agent. Oxidation reactions can produce free radicals, which start chain reactions that damage cells. Antioxidants terminate these chain reactions by removing free radical intermediates, and inhibit other oxidation reactions by being oxidized themselves. As a result, antioxidants are often reducing agents such as thiols, although oxidation reactions are crucial for life, they can also be damaging; hence, plants and animals maintain complex systems of multiple types of antioxidants, such as glutathione, vitamin $\mathrm{C}$, and vitamin $\mathrm{E}$ as well as enzymes such as catalase, superoxide dismutase and various peroxidases. Low levels of antioxidants, or inhibition of the antioxidant enzymes, cause oxidative stress and may damage or kill cells.

Now-a-day's worldwide believe on our ancient system of medication which is Ayurveda, As per the Ayurvedic concept of Preparations, Churna is a fine powder of a drug or drugs which is prepared by mixing clean, finely powdered and sieved drugs. Churna shows its effects mainly on gastrointestinal tract. It increases peristaltic movements of GI tract. It is used as ant flatulent (admana), ant rheumatic (amavata) all disease are allied disorders of Antioxidant Activity. It is also used in the treatment of abdominal disorders (udara roga), pain (sula) and in treatment of piles (arsa) etc Practitioners usually do the identification of different herbs used in Pancasama churna according to Ayurvedic parameters. The preparation of Churna is based on traditional methods in accordance with the procedures given in classical texts [1]. Due to lack of modern pharmacopoeial standards laid down and followed for processing of Churna, the medicine prepared using traditional methods may not have the desired quality and batch to batch consistency. Hence this formulation required standardization of following scientific parameters including organoleptic characters, chemical analysis, chromatographic pattern and microbial screening. The work was undertaken in trust as part of a program of testing and validation of traditional practice of using the Ayurvedic medicine formulation like churna in management of admana. Some standards already exist for Ayurvedic churna in Ayurvedic Pharmacopoeia. However, the work deals with the details of following latest standardization guidlines involving Good Manufacturing Practices (GMP) for preparation of Ayurvedic medicines. Standardization guidelines to be followed for herbal products provided by international bodies like World Health Organization (WHO),

${ }^{1}$ Corresponding Author: subhajitmpharm07@gmail.com 
European Agency for the evaluation of Medicinal Products (EMEA) and United States Pharmacopeia (USP) have also been considered.

The concept of developing drugs from plants used in indigenous medical system is much older, while in some cases direct links between a local and biomedical use exists, in other cases the relationship is much more complex ${ }^{[2]}$. Traditionally, 'Rasayana' drugs are used against a plethora of seemingly diverse disorders with no pathophysiological connections according to modern medical Sciences. Looking at these diverse applications adaptogenic agents from this group of 'Rasayanas' were identified ${ }^{[3]}$. It has been reported that the 'Rasayanas' are rejuvenators, nutritional supplements and possess strong antioxidant activity. They also have antagonistic actions on the oxidative stressors which giving rise to the formation of different free radicals. Therefore, the therapeutic indication of these drugs can include the diseases relating to all the above systems. Their antistress/adaptogenic actions have made them therapeutically far more important ${ }^{[4]}$. The strong antioxidant activity of any 'Rasayana' was found to be 1000 times more potent than ascorbic acid, $\alpha$-tocopherol, and probucol ${ }^{[5]}$. For example, oral administration of 'Brahma rasayana' (50 mg/animal for 10 and 30 days) significantly increased the liver antioxidant enzymes such as SOD, CAT along with tissue and serum levels of GSH. Thus, indicating that 'Brahma rasayana' could ameliorate the oxidative damage produced in the body by radiation ${ }^{[6]}$. 'Rasayana' preparations also increased stem cell proliferation and also prevented free radical-induced injury produced by radiation ${ }^{[7][8]}$ also reported the prevention of oxidant stress by 'Student Rasayana.

Since free radicals are implicated in a number of physiological disorders as described above and with the 'Rasayana' drugs of Ayurveda used in the treatment of diverse physiological disorders, there is a strong case to believe that 'Rasayana' drugs exert their therapeutic actions by their ability to scavenge free radicals or by their antioxidant potential. There has been a review on some plants of Indian traditional medicine with antioxidant activity ${ }^{[9]}$ and a review of immunemodulators from 'Ayurveda' especially of the 'Rasayana' drugs ${ }^{[10]}$. But there is not a single review of the 'Rasayana' drugs of the 'Ayurveda', as antioxidants. Some important plants like Allium sativum, Centella asiatica, Ocimum sanctum, Vitis vinifera and Zingiber officinale have been extensively reviewed in the recent past. Important 'Rasayana' drugs are reviewed for their antioxidant activity here. Most important antioxidants are here, so many times used in Ayurveda in different purposes also.

Acorus calamus :- Acorus calamus Linn. (family: Acoraceae, Ayurvedic name: 'Vacha') .

$>$ Aloe vera :- Aloe vera Linn. (family: Aloaceae, Ayurvedic name: 'Kumari').

$>$ Andrographis paniculata :- Andrographis paniculata (Burm. f.) Wall ex. Nees (family: Acanthaceae, Ayurvedic name: 'Kalmegh').

Asparagus racemosus :-Asparagus racemosus Willd. (family: Asparagaceae, Ayurvedic name: 'Shatavari').

$>$ Azadirachta indica :-Azadirachta indica A. Juss. (family: Meliaceae,Ayurvedic name: 'Nimba') is commonly known as neem.

> Bacopa monnieri :- Bacopa monnieri (Linn.) Penn. (family: Scrophulariaceae, Ayurvedic name: Brahmi).

$>$ Desmodium gangeticum :- Desmodium gangeticum (L.) DC. (family: Fabaceae, Ayurvedic name: 'Shalparni').

$>$ Phyllanthus emblica :- Phyllanthus emblica L. (family: Euphorbiaceae, Ayurvedic name: 'Amalaki') is considered best among 'Rasayana' so called 'Acharasayana' ${ }^{[7]}$.

> Glycyrrhiza glabra : Glycyrrhiza glabra Linn. (family: Fabaceae, Ayurvedic name: 'Yashtimadhu') is commonly known as licorice.

> Picrorhiza kurroa:- Picrorhiza kurroa Royle ex Benth (family: Scrophulariaceae, Ayurvedic name: 'Kutki').

> Psoralea corylifolia:-Psoralea corylifolia Linn. (family: Leguminoceae, Ayurvedic name: 'Vakuchi').

> Semecarpus anacardium :-Semecarpus anacardium Linn. f. (family: Anacardiaceae, Ayurvedic name: Bhalatak).

Terminalia chebula :-Terminalia chebula Retz. (family: Combretaceae, Ayurvedic name: 'Haritaki').

$>$ Tinospora cordifolia :-Tinospora cordifolia (Willd.) Miers. (family: Menispermaceae, Ayurvedic name: 'Guduchi').

Withania somnifera :-Withania somnifera Dunal (family: Solanaceae, Ayurvedic name: 'Ashwagandha') has been in use for more than 2500 years. 


\section{More Plants used as Rasayana Antioxidants}

Curculigo orchioides Gaertn. had high antioxidant activity in 2,2- azinobis [3-ethylbenzothiazoline-6-sulfonate] (ABTS) assay ${ }^{[11]}$. Hygrophila auriculata (Schum.) Hiene. extract showed good radical scavenging activity against DPPH with moderate scavenging activity against Nitric oxide, hydroxyl radical, ferryl bipyridyl Complex and LPO [12]. Alcoholic extract of the seeds of Mucuna pruriens (Linn.) DC. has an antilipid peroxidation property, which is mediated through the removal of superoxides and hydroxyl radicals ${ }^{[13]}$. The antioxidant components of Piper species, viz., Piper cubeba, green pepper, Piper brachystachyum, Piper longum and Piper nigrum constitute a very efficient system in scavenging a wide variety of reactive oxygen species. Antioxidant potential of Piper species was further confirmed by their ability to curtail in vitro LPO by around $30-50 \%$ with concomitant increase in GSH content ${ }^{[14]}$. In ferric reducing/antioxidant power (FRAP)/DPPH assays, boiled ethanolic extracts of Plumbago zeylanica $\mathrm{L}$. were the most effective, while in the ABTS assay boiled aqueous extracts were the most efficient. These extracts also significantly inhibited LPO induced by cumene hydroperoxide, ascorbate- $\mathrm{Fe}^{(2+)}$ and peroxynitrite. Thus, Extracts of Plumbago zeylanica and its active ingredient plumbagin have significant antioxidant abilities that may possibly explain some of the reported therapeutic effects ${ }^{[15]}$. ABTS assay showed that the ethanolic extract of Sida cordifolia L. was found to be most potent along with relative antioxidant capacity for the water infusions and potent inhibition of LPO. Evolvulus alsinoides and Cynodon dactylon were also found to be moderately active ${ }^{[16]}$.

As per literature Emblica officinalis [Syn: Phyllanthus Emblica] or Amla (Indian Gooseberry), Ocimum sanctum (Tulsi), Azadirachta indica (Neem), Ginger (Zingiber officinale Roscoe, Zingiberacae) Bitter melon(Karavella) Momordica charantia Linn,Family-Cucurbitaceae all the herbs having Anti-oxidants activity,so preparing an Ayurvedic formulation with two of them herbal ingredients and standardized that particular formulation.

2.1. Selection of Herbs Bitter melon Momordica charantia Linn,Family-Cucurbitaceae is easily available in market, Amla (Embilica Officinalis) is a seasonal friut and also easily available in markaet,both are common ingredients, cheap in compare to other herbal ingredients and already established about both are potent Anti-oxidant ingredient ${ }^{\left[{ }^{[17],[18]} \text {. }\right.}$.

2.2. Preparation of Churna Churna is a fine powder of a drug or drugs which is prepared by mixing clean, finely powdered and sieved drugs. The term churna may be applied to the powder prepared by a single drug or a combination of more drugs ${ }^{[19]}$. Ayurvedic formulary of India has given the specification for the composition of Churnas. ${ }^{[20],[21]}$.

\section{Methodology}

\subsection{Material and Methods}

\section{Plant Material}

The crude drugs used in preparation of Churna were collected from Nadaun in September 2014 and identified in Department of Botany, University of Rajasthan, Jaipur. One In - House formulation was prepared, as per the procedure mentioned in Ayurvedic text. An Antioxidant churna was prepared. This is a Polyherbal formulation, consisting of Bitter Melon Momordica charantia Linn \& Amla Embilica Officinalis ingredients in equal ratio (1:1), with specific morphological parts of the plants (herbs) used and each ingredient being of equal quantity. Take both the ingredients of pharmacopoeia quality, in a stainless steel pan at a low temperature till it becomes free from moisture. Powder the ingredients 1 to 2 individually in a pulverizer and pass through sieve number 85 . Weigh separately each ingredient, mix together in specified ratio (1:1) and pass through sieve number 44 to obtain a homogeneous blend. Pack it in tightly closed containers to protect from light and moisture. Store in a Cool and Dry place.

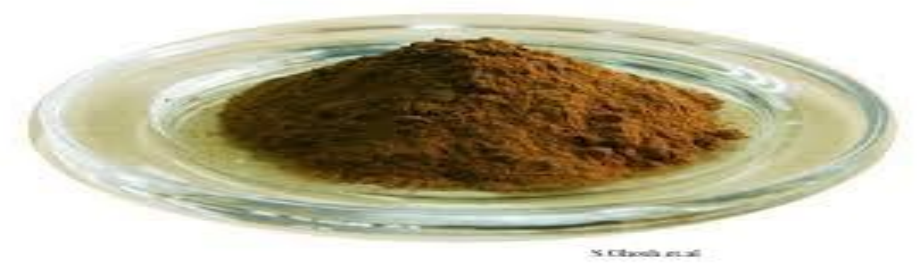

Fig1. After Mixing of both Ingredients in Equal Ratio 
American Research Journal of Pharmacy, Volume 1, Issue 1, February 2015

ISSN 2380-5706

\subsection{Formulation Composition}

Table1. Ingredients of An Antioxidant Churna

\begin{tabular}{|c|c|c|c|c|c|}
\hline Serial No. & Sanskrit name & English name & Scientific name & Part Used & Quantity \\
\hline 1. & Karavella & Bitter melon & $\begin{array}{c}\text { Momordicacharantia Lin, } \\
\text { Family-Cucurbitaceae }\end{array}$ & Fruit & 1 Part \\
\hline 2. & Amla & $\begin{array}{c}\text { Indian } \\
\text { Gooseberry }\end{array}$ & $\begin{array}{c}\text { Embilica Officinalis. } \\
\text { Family:-Phyllanthaceae. }\end{array}$ & Fruit & 1 Part \\
\hline
\end{tabular}

\section{ORGANOLEPTIC EVALUATION}

The material was examined for probable adulterants and foreign matter adhering to the surface was removed. Organoleptic evaluation was used for identification of sensory characteristics like colour, odour, taste, shape, size, texture and fracture.

\section{Physiochemical Investigation}

Physico chemical investigations of the formulations carried out including determination of extractive values, ash values and loss on drying by I R moisture balance.

\subsection{Loss on drying}

Loss on dying is the loss of mass expressed as percent w/w. About $10 \mathrm{~g}$ of samples of formulation was accurately weighed in a dried and tared flat weighing bottle and dried at $105^{\circ} \mathrm{C}$ for $5 \mathrm{hrs}$. Percentage was calculated with reference to initial weight.

\subsection{Determination of total ash}

Ashing involves an oxidation of the components of the products. A high ash value is indicative of contamination, substitution, adulteration or carelessness in preparing the formulation. Total ash determination constitutes detecting the physiological ash (ash derived from plant tissue) and non physiological ash (ash from extrageneous matter, especially sand and soil adhering to the surface of the drug). For its detection, $2 \mathrm{~g}$ of powdered material was placed in a suitable tared crucible of silica previously ignited and weighed. The powdered drug was spread into an even layer and weighed accurately. The material was incinerated by gradually increasing the heat, not exceeding $450^{\circ} \mathrm{C}$ until free from carbon, cooled in a desiccators, weighed and percentage ash was calculated by taking in account the difference of empty weight of crucible \& that of crucible with total ash.

\subsection{Determination of Acid insoluble ash}

The ash obtained as above was boiled for $5 \mathrm{~min}$ with $25 \mathrm{ml}$ of dilute hydrochloric acid; the insoluble matter was hot water and collected on an ashless filter paper, washed with ignited to constant weight. The percentage of acidinsoluble ash with reference to the air-dried drug was calculated.

\section{DETERMination OF SOLVENT EXTRACTIVE VALUES}

\subsection{Alcohol soluble extractive value}

$5 \mathrm{~g}$ of coarsely powdered air-dried formulation was macerated with $100 \mathrm{ml}$ of alcohol in a closed flask for twentyfour hours, shaking frequently during six hours and allowing standing for eighteen hours. It was then filtered rapidly; taking precautions against loss of solvent $25 \mathrm{ml}$ of the filtrate was evaporated to dryness in a tared flatbottomed shallow dish at $105^{\circ} \mathrm{C}$ to constant weight and weighed. The percentage of alcohol-soluble extractive was calculated with reference to the air dried drug and is represented as \% value.

\subsection{Water soluble extractive value}

$5 \mathrm{~g}$ of coarsely powdered air-dried formulation was macerated with $100 \mathrm{ml}$ of chloroform water in a closed flask for twenty-four hours, shaking frequently during six hours and allowed to stand for eighteen hours. It was then filtered rapidly, taking precautions against loss of solvent. $25 \mathrm{ml}$ of the filtrate was evaporated to dryness in a tared flat bottomed shallow dish at $105^{\circ} \mathrm{C}$ to constant weight and weighed. The percentage of water-soluble extractive was calculated with reference to the air-dried drug and is represented as \% value.

\subsection{Determination of $\mathrm{pH}$}

The $\mathrm{pH}$ of different batches of formulation were determined using $\mathrm{pH}$ paper (Range 3.5-6) and (6.5-14) with standard glass electrode. 


\section{Physical Characteristics of Powder}

Physical characteristics like bulk density, tap density, angle of repose, Hausner's ratio and Carr's index were determined for different formulations.

\subsection{Bulk density and Tape density}

The term bulk density refers to a measure used to describe a packing of particles or granules. The equation for determining bulk density $(\mathrm{Db})$ is: $\mathrm{Db}=\mathrm{M} / \mathrm{Vb}$ Where $\mathrm{M}$ is the mass of the particles and $\mathrm{Vb}$ is the total volume of the packing. The volume of the packing can be determined in an apparatus consisting of a graduated cylinder mounted on a mechanical tapping device (Jolting Volumeter) that has a specially cut rotating can. 100gm of weighed formulation powder was taken and carefully added to the cylinder with the aid of a funnel. Typically the initial volume was noted and the sample was then tapped until no further reduction in volume was noted. The initial volume gave the Bulk density value and after tapping the volume reduced, giving the value of tapped density.

\subsection{Angle of repose}

Angle of Repose has been used as an indirect method of quantifying powder flow ability; because of its relationship with interparticle cohesion. As a general guide, powders with angle of repose greater than 50 degree have unsatisfactory flow properties, whereas minimal angle close to 25 degrees correspond to very good flow properties. The fixed funnel and the free standing cone method employs a funnel that is secured with its tip at a given height, which was taken $2.5 \mathrm{~cm}(\mathrm{H})$, above the graph paper that is place on flat horizontal surface. Powder or granulation was carefully poured through the funnel until the apex of the conical pile just touched the tip of the funnel. Tan $\alpha=$ $H / R$ or $\alpha=\arctan H / R$

Where $\alpha$ is the angle of repose, $R$ being the radius of the conical pile.

\subsection{Hausner's ratio}

It is related to inter particle friction and as such can be used to predict the powder flow properties. Powders with low interparticle friction such as coarse spheres, have a ratio of approximately 1.2, whereas more cohesive, less flowable powders such as flakes have a Hausner's ratio greater than 1.6. The equation for measuring the Hausner's ratio is:

Hausner's ratio $=\mathrm{Df} / \mathrm{Do}$, where $\mathrm{Df}=$ Tapped density and Do $=$ Bulk density.

\subsection{Carr's index}

Another indirect method of measuring the powder flow from bulk density is Carr's index. The equation for measuring Carr's index is: \% compressibility $=(\mathrm{Df}-\mathrm{Do} / \mathrm{Do}) \times 100$ where $\mathrm{Df}=$ Tapped density and Do $=$ Bulk density.

\subsection{Phytochemical Screening}

Active phytochemical constituents like Alkaloids, glycosides, flavonoids, acids, gums, tannins, carbohydrates, proteins, fixed oils etc were identified through qualitative chemical analysis in each of the ingredients.

\subsection{Chromatographic Evaluation}

TLC was done (Fig.2) with water extract of Antioxidant churna. $5 \mathrm{gm}$ of sample (Water extract form prepared churna) in alcohol $(25 \mathrm{ml} \times 3)$ under reflux on a water-bath for $30 \mathrm{~min}$. Filter, concentrate to $10 \mathrm{ml}$ and carry out the thin layer chromatography. Apply $10 \mu \mathrm{l}$ of the extract on TLC plate, develop the plate to a distance of $8 \mathrm{~cm}$ using Benzene: Ethanol: Methanol (3:4:3) as mobile phase. After development of the plate, allow it to dry in air and examine under ultraviolet light $(254 \mathrm{~nm})$ and the spots were visualized after using Spraying reagent Vanilline- $\mathrm{H}_{2} \mathrm{SO}_{4}$ mixture. The $\mathrm{R}_{\mathrm{f}}$ Values ( Table-7) were calculated. 


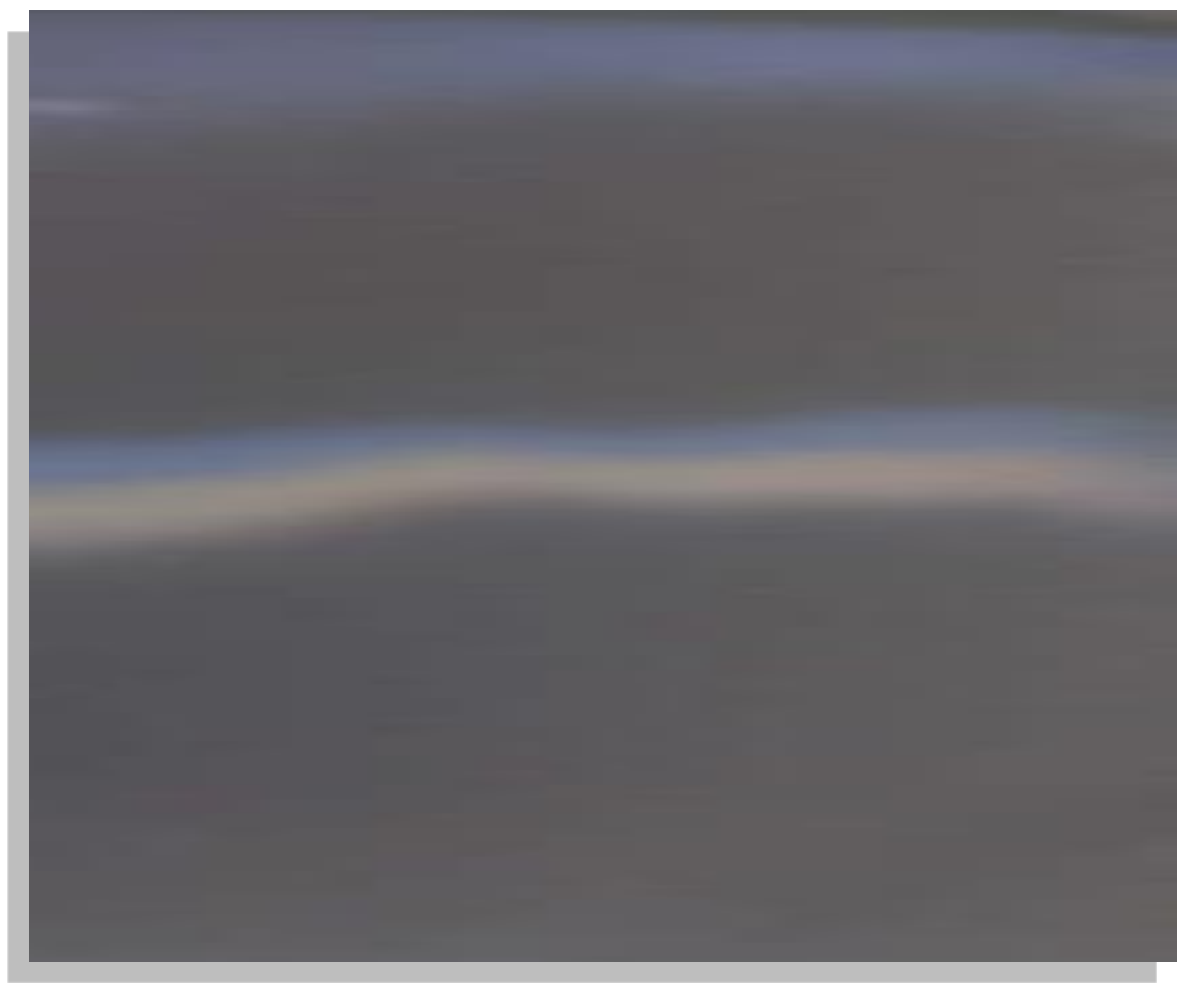

Fig2. TLC profile of Antioxidant Churna

\section{RESULT AND DISCUSSION}

In - House formulation was prepared with reference of Ayurvedic Formulary of India. As part of standardization procedure, the finished product Churna was tested for relevant physical and chemical parameters. The powders were smooth, having fragnant odour, possessing bitter taste. The Organoleptic properties of in-house formulations were reported in table 2 .

Table2. Organoleptic Character of Prepared Churna Including Ingredients

\begin{tabular}{|l|l|l|l|l|}
\hline S. No. & Parameters & Momordica charantia & Embilica officinalis & Prepared Churna \\
\hline 1 & Appearance & Powder & Powder & Powder \\
\hline 2 & Colour & Light Brown & Brown & Brown \\
\hline 3 & Odour & Astringent & Astringent & Astringent \\
\hline 4 & Taste & Bitter & Sour & Bitter \\
\hline
\end{tabular}

The physicochemical comparison of different batches of prepared formulation is given in Table 3. The results obtained with the different batches in-house formulations were found to be comparable and variation was insignificant.

Table3. Physiochemical Investigation of Prepared Churna

\begin{tabular}{|c|c|c|c|c|c|c|c|}
\hline \multirow{2}{*}{$\begin{array}{l}\text { S. } \\
\text { No }\end{array}$} & \multirow{2}{*}{ Parameter } & \multicolumn{5}{|c|}{ Prepared Churna (Different Batches) } & \multirow{2}{*}{$\begin{array}{l}\text { Mean values } \pm \\
\text { SEM }\end{array}$} \\
\hline & & Batch 1 & Batch 2 & Batch 3 & Batch 4 & Batch 5 & \\
\hline 1 & Loss on Drying $105^{\circ} \mathrm{C}$ & 4.86 & 5.20 & 4.90 & 5.00 & 5.60 & $5.112+0.1354$ \\
\hline 2 & $\begin{array}{l}\text { Water soluble Extractive } \\
\text { Value }(\%)\end{array}$ & 60.26 & 66.78 & 70.25 & 65.50 & 68.00 & $66.158 \pm 0.2889$ \\
\hline 3 & $\begin{array}{l}\text { Alcoholic Soluble } \\
\text { Extractive Value (\%) }\end{array}$ & 40.20 & 45.30 & 45.80 & 45.50 & 50.60 & $45.48 \pm 1.646$ \\
\hline 4 & Total Ash (\%) & 13.30 & 13.40 & 13.30 & 12.50 & 13.50 & $13.20 \pm 0.018$ \\
\hline 5 & Acid Insoluble Ash (\%) & 0.70 & 0.70 & 0.70 & 0.80 & 0.70 & $0.72 \pm 0.0194$ \\
\hline 6 & $\mathrm{p}^{\mathrm{H}}$ & 4.4 & 5.8 & 5.5 & 5.5 & 4.5 & $5.14 \pm 0.287$ \\
\hline
\end{tabular}


The physical characteristics of the in-house formulation (average values along with standard deviation) $(\mathrm{n}=5)$ are shown in Table 4. The results of the In - House formulation indicate that flow ability of the formulation was found to be poor, which was further confirmed by high values of Hausner ratio \& Carr's Index.

Table4. Physical Characters of Prepared Churna

\begin{tabular}{|l|l|l|l|}
\hline S. No. & Parameters & Results & \\
\cline { 3 - 4 } & & CGS Units & S.I Units \\
\hline 1 & Bulk Density & $0.4436 \pm 0.002(\mathrm{gm} / \mathrm{ml})$ & $443.6 \pm 0.184\left(\mathrm{~kg} / \mathrm{m}^{3}\right)$ \\
\hline 2 & Tapped Density & $0.6240 \pm 0.012(\mathrm{gm} / \mathrm{ml})$ & $624 \pm 1.363\left(\mathrm{~kg} / \mathrm{m}^{3}\right)$ \\
\hline 3 & Carr's Index & $40.66 \%$ & \\
\hline 4 & Hauner's Ratio & $1.40 \pm 0.4$ & \\
\hline 5 & Angle of Repose & $30.7 \pm 0.2$ & \\
\hline
\end{tabular}

The result obtained for phytochemical screening reveals that phytoconstituents like glycosides, carbohydrates, alkaloid and flavonoids were present in prepared In - House formulation (Table 5). Above study indicate that some constituent carried by one ingredient (Momordica charantia) \& some by the other (Embilica officinalis). So combination of these two contains maximum activities which are responsible for further investigation.

Table5. Phytochemical screening of Prepared Churna

\begin{tabular}{|l|l|l|l|l|}
\hline S. No. & Phytoconstituent & Momordica charantia & Embilica officinalis & Prepared Churna \\
\hline 1 & Glycoside & Positive & Negative & Positive \\
\hline 2 & Alkaloids & Positive & Negative & Positive \\
\hline 3 & Tannins & Positive & Positive & Positive \\
\hline 4 & Saponins & Negative & Positive & Positive \\
\hline 5 & Flavonoids & Negative & Positive & Positive \\
\hline 6 & Phenols & Positive & Positive & Positive \\
\hline 7 & Sterols & Positive & Negative & Positive \\
\hline 8 & Proteins & Positive & Negative & Positive \\
\hline
\end{tabular}

The Chromatographic Investigation of different batches of in-house formulation (average values along with standard deviation) $(\mathrm{n}=5)$ are shown in Table 6 . Rf Value calculated and shown in Table 6.

Table6. Chromatographic Investigation of Prepared Churna

\begin{tabular}{|l|l|l|l|l|l|l|l|}
\hline $\begin{array}{l}\text { S. } \\
\text { No. }\end{array}$ & Parameter & \multicolumn{3}{|l|}{ Prepared Churna (Different Batches) } & \multirow{2}{*}{ Mean values \pm SEM } \\
\cline { 2 - 7 } & & Batch 1 & Batch 2 & Batch 3 & Batch 4 & Batch 5 & \\
\hline & $\begin{array}{l}\text { TLC(No of } \\
\text { spots ) }\end{array}$ & 1.00 & 1.00 & 1.00 & 1.00 & 1.00 & $\mathbf{1 . 0 0 \pm 0 . 0 0}$ \\
\hline $\mathbf{2}$ & $\mathbf{R}_{\mathbf{f}}$ Value & 0.76 & 0.75 & 0.78 & 0.76 & 0.72 & $\mathbf{0 . 7 5 4} \pm \mathbf{0 . 0 0 9 7 9}$ \\
\hline
\end{tabular}

\section{CONCLUSION}

From the present investigation various standardization parameters such as organoleptic study, Physiochemical study, Physical characters, phytochemical \& Chromatographic evaluation were carried out. It can be concluded that the In House formulation of churna was in accordance with the standards laid down for churna. The study shows that the contents of formulation present with in permissible limits as per WHO, contents of formulation and their standardization give a point of view for further research investigation. The result of present study will may be serve as reference monograph in the preparation of drug formulation. For further research these studies play a vital role in reference of biological approach.

\section{ACKNowledgment}

The authors gratefully acknowledge to our,The Ayurvedic Formulary of India. Government of India, Ministry of Health and Family Welfare, New Delhi, The Ayurvedic Pharmacopoeia of India, Government of India, Ministry of Health and Family Welfare, New Delhi and the supports of Prof.(Dr.) R. Parthasarathy, ( Principal ) Department of Pharmacognosy,as well as Mr.Ashok Sharma Sir, Himachal Institute Of Pharmaceutical Education \& Research, Nadaun, Hamirpur, Himachal Preadesh, India and Special thanks to Mr.Sambhu Nath Ghosh,Mrs.Kalayani Ghosh.For providing all facility to complete this work successfully . 


\section{REFERENCES}

[1] Anonymous, The Ayurvedic Formulary of India. Government of India, Ministry of Health and Family Welfare, New Delhi, 2003, 113.

[2] Heinrich M, Gibbons S, Ethnopharmacology in drug discovery: an analysis of its role and potential contributions, Journal of Pharmacy and Pharmacology, 53 (2001) 425-432.

[3] Rege NN, Thatte UM, Dahanukar SA, Adaptogenic properties of six Rasayana herbs used in Ayurvedic medicine, Phytotherapy Research, 13 (1999) 275-291.

[4] Brahma SK, Debnath PK, Therapeutic importance of Rasayana drugs with special reference to their multidimensional actions, Arya vaidyan, 16 (2001) 160-163.

[5] Sharma HM, Hanna AN, Kauffman EM, Newman HAI, Inhibition of human low-density lipoprotein oxidation in vitro by Maharishi Ayurveda herbal mixtures, Pharmacology Biochemistry and Behavior 43 (1999) 11751182.

[6] Rekha PS, Kuttan G, Kuttan R, Effect of Brahma Rasayana on antioxidant system after radiation, Indian Journal of Experimental Biology 39 (2001) 1173-1175.

[7] Puri HS, Rasayana-Ayurvedic herbs for longevity and rejuvenation, Taylor and Francis, London, 2002.

[8] Hanna AN, Kauffman EM, Newman HA, Sharma HM, Prevention of oxidant stress by Student Rasayana (SR), Advanced Experimental Medical Biology 366 (1999) 444-445.

[9] Scartezzini P, Speroni E, Review on some plants of Indian traditional medicine with antioxidant activity, Journal of Ethnopharmacology, 71 (2000) 23-43.

[10] Agarwal SS, Singh VK, Immunomodulators: a review of studies on Indian medicinal plants and synthetic peptides. Proceedings of Indian Science Academy, 65, (1999) 179-204.

[11] Tang SY, Whiteman M, Peng ZF, Jenner A, Yong EL, Halliwell B, Characterization of antioxidant and antiglycation properties and isolation of active ingredients from traditional chinese medicines. Free Radical Biology and Medicine 36 (2004) 1575-1587.

[12] Vijayakumar M, Govindarajan R, Shirwaikar A, Kumar V, Rawat AKS, Mehrotra S, Pushpangadan P, Free radical scavenging and lipid peroxidation inhibition potential of Hygrophila auriculata, Natural Product Sciences, 11 (2005) 61-66.

[13] Tripathi YB, Upadhyay AK, Effect of the alcohol extract of the seeds of Mucuna pruriens on free radicals and oxidative stress in albino rats, Phytotherapy Research, 16 (2002)534-538.

[14] Karthikeyan J, Rani, P, Enzymatic and non-enzymatic antioxidants in selected Piper species. Indian Journal of Experimental Biology, 41 (2003)135-140.

[15] Tilak JC, Adhikari S, Devasagayam TP, Antioxidant properties of Plumbago zeylanica, an Indian medicinal plant and its active ingredient, plumbagin, Redox Reports, 9 (2014) 219-227.

[16] Auddy B, Ferreira M, Blasina F, Lafon L, Arredondo F, Dajas F, Tripathi PC, Seal T, Mukherjee B, Screening of antioxidant activity of three Indian medicinal plants, traditionally used for the management of neurodegenerative diseases, Journal of Ethnopharmacology, 84 (2003) 131-138.

[17] Yasser FM, Kishk Hemat E, Sheshetawy, Indian Medicine, World Journal of Dairy \& Food Sciences, 5(2) (2010) 188-196.

[18] Islam Shahidul, Jalaluddin Mohammad, Navam S, Functional Foods in Heals and Disease, 2: (2011) 61-74.

[19] The Ayurvedic Pharmacopoeia of India, Government of India, Ministry of Health and Family Welfare, New Delhi, 2007, 1: 38.

[20] The Ayurvedic Formulary of India, Government of India, Ministry of Health and Family Welfare, New Delhi, Part-I, 2000, 31.

[21] The Ayurvedic Pharmacopoeia of India, Government of India, Ministry of Health and Family Welfare, New Delhi, $1^{\text {st }}$ edn, 2001, 1: 162.

[22] Lala PK, Lab Manuals of Pharmacognosy, $5^{\text {th }}$ Edition, CSI Publishers and Distributors, Calcutta, 1993.

[23] Ananymous, Quality Control Methods for Medicinal Plant Materials, World Health Organization, Geneva, 1998, 25-28. 